\title{
FSH activates phosphatidylinositol 3-kinase/protein kinase B signaling pathway in 20-day-old Sertoli cells independently of IGF-I
}

\author{
S B Meroni, M F Riera, E H Pellizzari, M N Galardo and \\ S B Cigorraga
}

Centro de Investigaciones Endocrinológicas (CEDIE), Hospital de Niños 'R. Gutiérrez', Gallo 1330, 1425 Buenos Aires, Argentina

(Requests for offprints should be addressed to S B Cigorraga; Email: scigorraga@cedie.org.ar)

\begin{abstract}
The gonadotropin FSH plays a key role in the control of Sertoli cell function. The FSH molecular mechanism of action is best recognized for its stimulation of the adenylyl cyclase/cAMP pathway. However, other signaling events have also been demonstrated in Sertoli cells. We have recently presented evidence that FSH can stimulate the phosphatidylinositol 3-kinase/protein kinase B (PI3K/ $\mathrm{PKB})$ pathway in 20-day-old Sertoli cells. At the same time, it was proposed that in 8-day-old Sertoli cells the effects of FSH on phosphorylated PKB (P-PKB) levels can be explained by a combination of increased secretion of endogenous IGF-I, decreased IGF-binding protein-3 (IGFBP-3) production, and a synergistic action of FSH on IGF-I-dependent PI3K activation. The aim of the present study was to determine whether the effect of FSH on 20-day-old Sertoli cells is mediated by IGF-I secretion. Twenty-day-old rat Sertoli cell cultures were used. FSH stimulation produced a time-dependent increment in P-PKB levels reaching maximal values in 60-min incubations. IGF-I stimulation was also time-dependent reaching maximal values in 15-min incubations. On the other hand, stimulation of the cultures with FSH showed timedependent inhibition in phosphorylated mitogen-activated protein kinase (P-MAPK) levels. In sharp contrast, stimulation of the cultures with IGF-I showed time-dependent increments in P-MAPK levels reaching maximal stimulus
\end{abstract}

in 15-min incubations. In order to rule out an IGF-I action on FSH stimulation of P-PKB levels, the effect of a specific IGF-I antibody on the ability of both hormones to increase P-PKB levels was evaluated. As expected, the antibody inhibited IGF-I stimulation of P-PKB levels. However, simultaneous addition of an IGF-I antibody with FSH did not modify the ability of the hormone to increase P-PKB levels. The next set of experiments intended to analyze the relevance of a PI3K/PKB pathway to two biological responses of Sertoli cells to FSH and IGF-I. The PI3K inhibitor, wortmannin, dosedependently decreased FSH-stimulated lactate and transferrin production. On the other hand, wortmannin was not able to modify the ability of IGF-I to stimulate these metabolic events. In addition, the analysis of the participation of a MAPK pathway in IGF-I regulation of Sertoli cell biological responses showed that the MAPK kinase inhibitors, PD98059 and U0126, decreased IGF-Istimulated transferrin secretion while not modifying IGFI-stimulated lactate levels. In summary, results obtained so far support the hypothesis that FSH action on P-PKB levels and Sertoli cell metabolism in 20-day-old animals is not mediated by autocrine regulation of an IGF-I/ IGFBP-3 axis as previously proposed in 8-day-old Sertoli cells.

Journal of Endocrinology (2004) 180, 257-265

\section{Introduction}

The gonadotropin follicle-stimulating hormone (FSH) plays a key role in the control of Sertoli cell function. FSH determines the number of Sertoli cells that will be present in adult males by its ability to control proliferation at the neonatal stage (Orth 1982). In the rat, Sertoli cell mitosis ceases by day 15 and FSH then takes over the control of differentiation of these cells that are essential to sustain a qualitatively and quantitatively normal spermatogenesis (Griswold 1993). The FSH molecular mechanism of action is best recognized for its stimulation of the adenylyl
cyclase/cAMP pathway via activation of a $G$ protein. Elevated cAMP levels lead to the activation of protein kinase A (PKA) that phosphorylates several protein substrates. The ability to stimulate the adenylyl cyclase/ cAMP pathway decreases with age (Steinberger et al. 1978). In addition to the cAMP/PKA pathway, other signaling events that include increased intracellular $\mathrm{Ca}^{2+}$ levels (Grasso \& Reichert 1989, Gorczynska \& Handelsman 1991), activation of phospholipase $A_{2}$ (Jannini et al. 1994) and nuclear factor kappa B translocation (Delfino \& Walker 1998) have been demonstrated in Sertoli cells. Even though it has been established 
that there is no phosphoinositide turnover in response to FSH stimulation in Sertoli cells (Monaco et al. 1988), it has been shown that a protein kinase C (PKC)-dependent pathway can modulate Sertoli cell response to FSH (Lambert et al. 1991, Meroni et al. 1997). Moreover, FSH has been shown to trigger both activation and inhibition of the mitogen-activated protein kinase (MAPK) pathway depending on the maturation state of Sertoli cells (Crepieux et al. 2001).

Recently, links between $G$ protein-coupled receptors, cAMP, phosphatidylinositol 3-kinase (PI3K) and protein kinase $\mathrm{B}$ (PKB) signaling pathways have been observed (Richards 2001). In this regard, we have recently presented evidence that FSH can stimulate the PI3K/PKB pathway in 20-day-old Sertoli cells. We have observed that FSH increases phosphorylated PKB (P-PKB) levels in a PI3K-dependent and PKA-independent manner. In addition, we have observed that wortmannin partially inhibits the ability of FSH to stimulate two well-known parameters of Sertoli cell function and these results suggested a meaningful role of the PI3K/PKB pathway in the mechanism of action of FSH in rat Sertoli cells (Meroni et al. 2002). At the same time, Khan et al. (2002) proposed that in 8-day-old Sertoli cells the effects of FSH on P-PKB levels can be explained by a combination of increased secretion of endogenous insulin-like growth factor-I (IGFI), decreased IGF-binding protein 3 (IGFBP-3) production, and a synergistic action of FSH on IGF-I-dependent PI3K activation. The latter results made us wonder whether the effects of FSH that we observed on P-PKB levels and Sertoli cell metabolism in 20-day-old rats could be explained by endogenously produced IGF-I. To look into this issue we have searched for differential actions of both hormones. In this context we have analyzed: (a) the effects of FSH and IGF-I on P-PKB and phosphorylated MAPK (P-MAPK) levels and (b) a possible effect of a specific IGF-I antibody on the stimulatory action of FSH on P-PKB levels. Looking for additional evidence to sustain the hypothesis that the effect of FSH on 20-day-old Sertoli cells is not due to IGF-I, we have analyzed the participation of the PI3K/PKB and MAPK pathways in the mechanism of action of both FSH and IGF-I that is utilized to regulate two Sertoli cell biological responses lactate and transferrin secretion.

\section{Materials and Methods}

\section{Materials}

Ovine FSH (NIH-oFSH-S-16) and monoclonal IGF-I antibody were obtained from the National Hormone and Pituitary Program, National Institute of Diabetes, Digestive and Kidney Diseases (NIDDK), Bethesda, MD, USA. Wortmannin, PD98059 and U0126 were purchased from Biomol (Plymouth Meeting, PA, USA). Kodak X-Omat S films were purchased from Eastman Kodak (Rochester,
NY, USA). All other drugs and reagents were obtained from Sigma-Aldrich (St. Louis, MO, USA).

\section{Sertoli cell isolation and culture}

Sertoli cells from 20-day-old Sprague-Dawley rats were isolated as previously described (Meroni et al. 1999). Briefly, decapsulated testes were digested with $0 \cdot 1 \%$ collagenase and $0 \cdot 006 \%$ soybean trypsin inhibitor in Hanks' balanced salt solution for $5 \mathrm{~min}$ at room temperature. Seminiferous tubules were saved, cut and submitted to $1 \mathrm{M}$ glycine- $2 \mathrm{mM}$ EDTA ( $\mathrm{pH} 7 \cdot 4)$ treatment to remove peritubular cells. The washed tubular pellet was then digested again with collagenase for $10 \mathrm{~min}$ at room temperature to remove germinal cells. The Sertoli cell suspension, collected by sedimentation, was resuspended in culture medium which consists of a 1:1 mixture of Ham F12 and Dulbecco's modified Eagle's medium, supplemented with $20 \mathrm{mM}$ HEPES, $100 \mathrm{IU} / \mathrm{ml}$ penicillin, $2.5 \mu \mathrm{g} / \mathrm{ml}$ amphotericin $\mathrm{B}, 1.2 \mathrm{mg} / \mathrm{ml}$ sodium bicarbonate, $10 \mu \mathrm{g} / \mathrm{ml}$ transferrin, $5 \mu \mathrm{g} / \mathrm{ml}$ insulin, $5 \mu \mathrm{g} / \mathrm{ml}$ vitamin $\mathrm{E}$ and $4 \mathrm{ng} / \mathrm{ml}$ hydrocortisone. Sertoli cells were cultured in 6- or 24-multiwell plates $\left(5 \mu \mathrm{g} D N A / \mathrm{cm}^{2}\right)$ at $34{ }^{\circ} \mathrm{C}$ in a mixture of $5 \% \mathrm{CO}_{2}: 95 \%$ air.

No myoid cell contamination was revealed in the cultures when an immunoperoxidase technique was applied to Sertoli cell cultures using a specific antiserum to alpha smooth muscle actin. Remaining cell contaminants were of germ cell origin and this contamination was below $5 \%$ after $48 \mathrm{~h}$ in culture as examined by phase contrast microscopy.

\section{Culture conditions}

Sertoli cells were allowed to attach for $48 \mathrm{~h}$ in the presence of insulin, and medium was replaced at this time with fresh medium without insulin. Either FSH or IGF-I was added to cells cultured on 24-multiwell plates on day 3 as indicated in the Figure legends. The $72-\mathrm{h}$ conditioned media obtained on day 6 were used to evaluate transferrin and lactate levels.

Cells cultured on 6-multiwell plates harvested on day 6, pretreated as indicated in the Figure legends, were used for Western blot analysis of P-PKB and P-MAPK levels.

\section{Transferrin determination}

Rat transferrin was measured by RIA as described by Handelsman et al. (1989). A polyclonal antibody raised against rat transferrin in rabbits was used (Cappel Laboratories, Cochranville, PA, USA). The crossreactivity of human transferrin in this assay is less than $0 \cdot 003 \%$. This RIA has a sensitivity of $3 \mathrm{ng} /$ tube and 
intra- and interassay coefficients of variation are $7 \%$ and $16 \%$ respectively.

\section{Lactate determination}

Lactate was measured by a standard method involving conversion of $\mathrm{NAD}^{+}$to $\mathrm{NADH}$ determined as the rate of increase of absorbance at $340 \mathrm{~nm}$. A commercial kit from Sigma-Aldrich was used.

\section{Cell extracts and Western blot analysis}

On day 6, cells pretreated for variable periods of time as indicated in the Figure legends were washed once with PBS at room temperature. Then, $200 \mu \mathrm{l}$ PBS containing $20 \mu \mathrm{l}$ of a protease inhibitor cocktail from Sigma-Aldrich (P-8340) and $2 \mathrm{mM}$ phenylmethylsulfonylfluoride were added to the cells. Cells were then placed on ice and disrupted by ultrasonic irradiation. A $200 \mu \mathrm{l}$ volume of $2 \times$ Laemmli buffer (Laemmli, 1970) was added and thoroughly mixed. Samples were immersed in a boiling water bath for $5 \mathrm{~min}$ and then immediately settled on ice. Proteins were resolved in 10\% SDS-PAGE and electrotransferred onto PVDF membranes (Hybond-P, Amersham Pharmacia Biotech, UK). Membranes were probed with commercial kits (Phosphoplus Akt (Ser 473) antibody kit and Phosphoplus p44/42 MAP kinase (Thr202/Tyr204) antibody kit, New England Biolabs, Inc., Beverley, MA, USA) that allow specific recognition of both total (T-PKB and T-MAPK) and phosphorylated (P-PKB and P-MAPK) PKB and MAPK. The intensities of the autoradiographic bands were estimated by densitometric scanning using NIH Image software (Scion Corporation, Frederick, MD, USA).

\section{Other assays}

DNA was determined by the method of Labarca \& Paigen (1980).

\section{Statistical analysis}

All experiments were run in triplicate and repeated three to four times. Results are expressed as means \pm S.E Oneway ANOVA with Tukey-Kramer or Dunnett's post test was performed using GraphPad InStat version 3.00 for Windows 95 (GraphPad Software, San Diego, CA, USA). Probabilities $<0 \cdot 01$ were considered statistically significant.

\section{Results}

\section{Effects of FSH and IGF-I on P-PKB levels}

Sertoli cell cultures were stimulated for variable periods of time with either $100 \mathrm{ng} / \mathrm{ml} \mathrm{FSH}$ or $50 \mathrm{ng} / \mathrm{ml} \mathrm{IGF-I.} \mathrm{A}$ low level of P-PKB in basal cultures was observed. FSH stimulation produced a time-dependent increment in P-PKB levels reaching maximal values in 60-min incubations (Fig. 1A). IGF-I stimulation was also timedependent reaching maximal values in 15-min incubations (Fig. 1B).

\section{Effects of FSH and IGF-I on P-MAPK levels}

In identical conditions to those described for Fig. 1, the ability of either $100 \mathrm{ng} / \mathrm{ml} \mathrm{FSH}$ or $50 \mathrm{ng} / \mathrm{ml}$ IGF-I to regulate the levels of P-MAPK was evaluated. Detectable levels of P-MAPK in basal cultures were observed. Stimulation of the cultures with FSH showed time-dependent inhibition in P-MAPK levels (Fig. 2A) as previously described (Crepieux et al. 2001). In sharp contrast, stimulation of the cultures with IGF-I showed time-dependent increments in P-MAPK levels reaching maximal values in 15-min incubations (Fig. 2B).

Effect of a specific IGF-I antibody on the stimulation of P-PKB levels produced by IGF-I and FSH

In the next set of experiments the effect of a specific IGF-I antibody on the ability of FSH and IGF-I to increase P-PKB levels was evaluated. Sertoli cell cultures were incubated with FSH or IGF-I in the presence or absence of a monoclonal IGF-I antibody for $60 \mathrm{~min}$. Figure 3 shows that the antibody, as expected, inhibited IGF-I stimulation of P-PKB levels (Fig. 3B). However, simultaneous addition of an IGF-I antibody with FSH did not modify the ability of the hormone to increase P-PKB levels (Fig. 3A).

Participation of PI3K/PKB- and MAPK-dependent pathways on the regulation of transferrin and lactate production by FSH and IGF-I

As mentioned before, FSH does not stimulate P-MAPK levels but it does stimulate P-PKB levels. In a previous report (Meroni et al. 2002), it was shown that this stimulation is blocked by the simultaneous presence of the PI3K inhibitor, wortmannin, in the incubation medium. As for IGF-I, which stimulates both signaling pathways, experiments to determine whether wortmannin and the MAPK kinase inhibitors PD98059 and U0126 were able to block the stimulatory effects of IGF-I on P-PKB and P-MAPK levels were performed. Figure 4 shows that wortmannin (Fig. 4A) and PD98059 and U0126 (Fig. 4B) decreased the ability of IGF-I to stimulate P-PKB and P-MAPK levels respectively.

The next set of experiments was designed to analyze the relevance of the PI3K/PKB and MAPK pathways to the regulation of Sertoli cell function by FSH and IGF-I. Figure 5 shows the experiments performed in order to analyze the participation of the PI3K/PKB pathway in the 

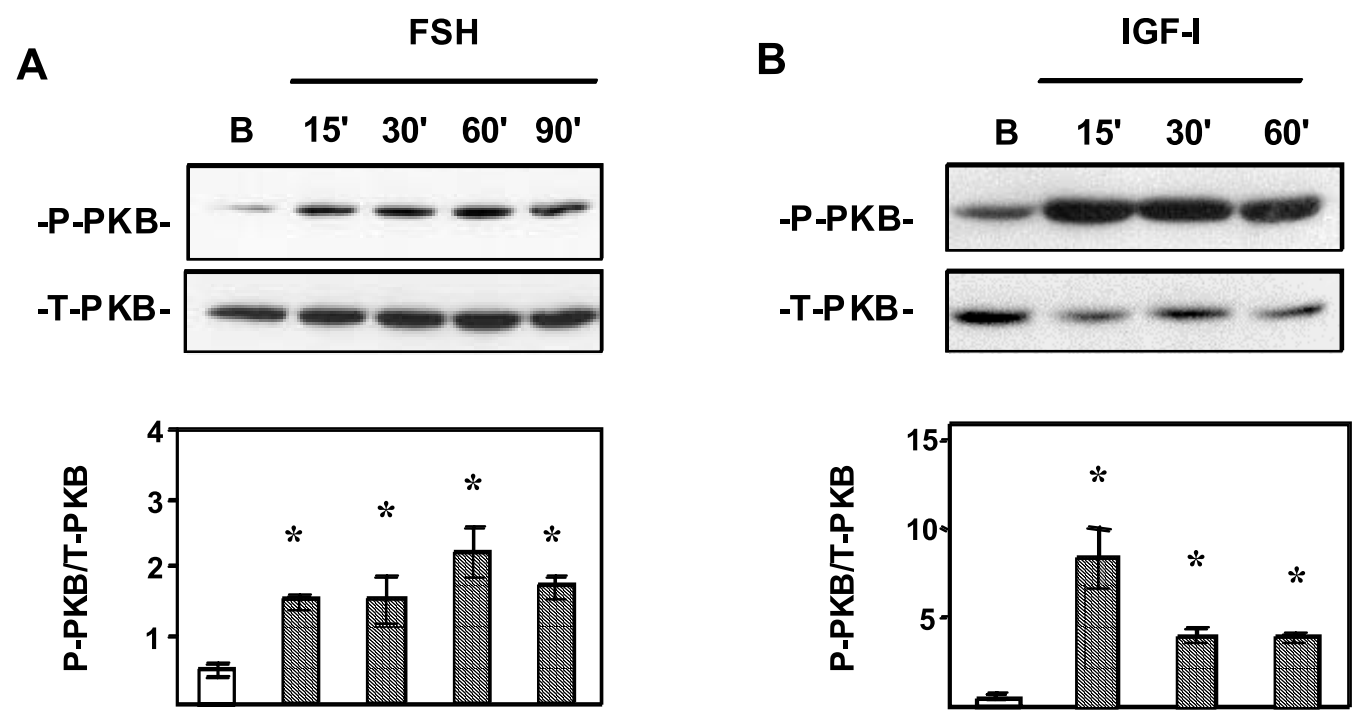

Figure 1 FSH and IGF-I regulate P-PKB levels in 20-day-old rat Sertoli cells. (A) Sertoli cells were stimulated for variable periods of time $(15,30,60$ or $90 \mathrm{~min})$ with $100 \mathrm{ng} / \mathrm{ml} \mathrm{FSH}$. (B) Sertoli cells were stimulated for variable periods of time $(15,30$ or $60 \mathrm{~min})$ with $50 \mathrm{ng} / \mathrm{ml}$ IGF-I. Cell extracts were prepared at the designated intervals and utilized for Western blot analysis using antibodies specific for total PKB (T-PKB) or phosphorylated PKB (P-PKB). Upper panels show a representative experiment out of four. Lower panels show pooled data of the four independent experiments performed. Results are expressed as the mean \pm S.E. of the ratio between P-PKB and T-PKB in each sample ( ${ }^{*} P<0 \cdot 01 \mathrm{vs}$ basal).

A

-P-MAPK-

-T-MAPK-

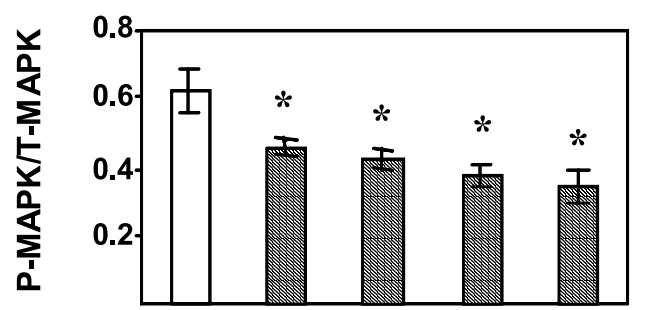

FSH

\section{B $\quad 1^{15^{\prime}} \quad 30^{\prime} \quad 60^{\prime} \quad 9^{\prime}$}
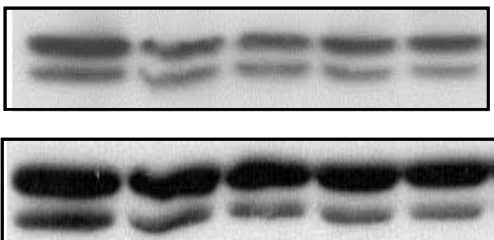

B

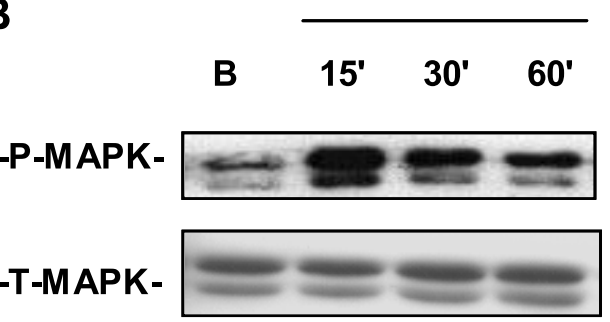

Figure 2 FSH and IGF-I regulate P-MAPK levels in 20-day-old rat Sertoli cells. (A) Sertoli cells were stimulated for variable periods of time $(15,30,60$ or $90 \mathrm{~min})$ with $100 \mathrm{ng} / \mathrm{ml} \mathrm{FSH}$. (B) Sertoli cells were stimulated for variable periods of time (15, 30 or $60 \mathrm{~min}$ ) with $50 \mathrm{ng} / \mathrm{ml}$ IGF-l. Cell extracts were prepared at the designated intervals and utilized for Western blot analysis using antibodies specific for total MAPK (T- MAPK) or phosphorylated MAPK (P-MAPK). Upper panels show a representative experiment out of four. Lower panels show pooled data of the four independent experiments performed. Results are expressed as the mean \pm S.E. of the ratio between P-MAPK and T-MAPK in each sample $\left({ }^{*} P<0 \cdot 01\right.$ vs basal).

regulation of lactate and transferrin production by $\mathrm{FSH}$ and IGF-I. The upper panels show that wortmannin dose-dependently decreased FSH-stimulated lactate and transferrin production. On the other hand, the lower panels show that wortmannin was not able to modify the ability of IGF-I to stimulate lactate or transferrin secretion. Finally, Fig. 6 shows the experiments performed in order to analyze the participation of the MAPK pathway in 
A
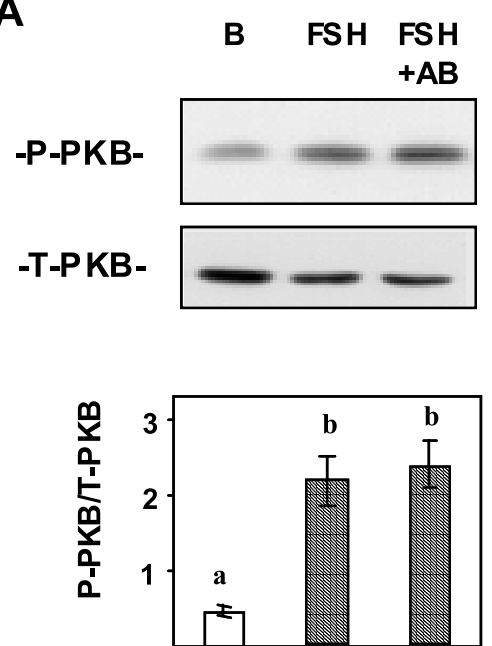

B
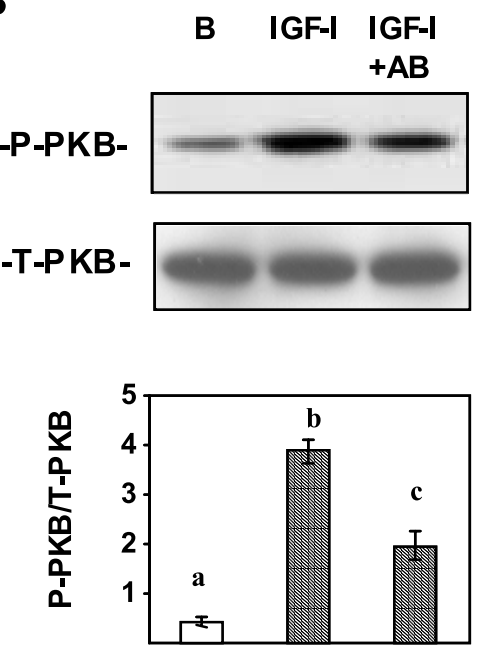

Figure 3 Effect of a monoclonal IGF-I antibody on FSH and IGF-I stimulation of P-PKB levels. Sertoli cells were stimulated for $60 \mathrm{~min}$ with $100 \mathrm{ng} / \mathrm{ml} \mathrm{FSH} \mathrm{(A)} \mathrm{or} 50 \mathrm{ng} / \mathrm{ml} \mathrm{IGF-I}$ (B) in the absence or presence of a 1/10 000 final dilution of a monoclonal IGF-I antibody (AB). Cell extracts were prepared at the designated intervals and utilized for Western blot analysis using antibodies specific for total PKB (T-PKB) or phosphorylated PKB (P-PKB). Upper panels show a representative experiment out of four. Lower panels show pooled data of the four independent experiments performed. Results are expressed as the mean \pm S.E. of the ratio between P-PKB and T-PKB in each sample. Different letters indicate statistically significant differences $(P<0 \cdot 01)$.

IGF-I regulation of Sertoli cell function. This Figure shows that PD98059 and U0126 decreased IGF-I-stimulated transferrin production (Fig. 6A) while they did not modify lactate production (Fig. 6B).

\section{Discussion}

The control of Sertoli cell proliferation and differentiation by FSH is complex. The physiological function of FSH in males will be better understood when the signaling pathways that mediate mitosis and those which allow differentiation are clarified. Upon binding of FSH to its specific receptor, activation of adenylyl cyclase results in the consequent increase in cAMP levels and PKA activation. Other signaling pathways that participate in the mechanism of action of FSH have been reviewed in the Introduction. As previously mentioned also in the Introduction, links between G protein-coupled receptors, cAMP, PI3K and PKB signaling pathways have recently been observed. Cass et al. (1999) have shown that thyrotropin stimulates the phosphorylation of PKB in a PI3K-dependent pathway in a thyroid cell line. In addition, Gonzalez-Robayna et al. (2000) have presented evidence that in granulosa cells FSH increases PKB phosphorylation in a way that is cAMP-dependent, PKA-independent but PI3Kdependent. As for the ability of FSH to regulate the $\mathrm{PI} 3 \mathrm{~K} / \mathrm{PKB}$ signaling pathway in rat Sertoli cells, two independent reports, which utilize Sertoli cells at a differ- ent stage of maturation, have been presented. On the one hand, Meroni et al. (2002) suggested that activation of the PI3K/PKB signaling pathway in 20-day-old Sertoli cells may be relevant to the mechanism of action of FSH in a similar way to that proposed by Gonzalez-Robayna et al. (2000) in granulosa cells. On the other hand, based on previous studies showing that FSH increases IGF-I secretion while it decreases IGFBP levels in Sertoli cell cultures (Cailleau et al. 1990), Khan et al. (2002) proposed that in 8-day-old Sertoli cells the ability of FSH to increase P-PKB levels in 60-min incubations can be accounted for by a combination of increased secretion of endogenous IGF-I, decreased IGFBP-3 production, and a synergistic action of FSH on IGF-I-dependent PI3K activation.

A marked difference in the differentiation state of Sertoli cells between 8- and 20-day-old rats is present. Sertoli cell proliferation during fetal and peri-natal life occurs until cells establish tight junctions to organize as a blood-testis barrier, which is completed at day 19 in rats (Orth 1984). In this context, FSH regulates Sertoli cell proliferation in 8-day-old animals while in 20-day-old animals the action of FSH is not related to mitosis but to the terminal differentiation that the Sertoli cell suffers at this point of sexual maturation. In connection with the above-mentioned differential effects of FSH, it has been demonstrated that this hormone triggers both activation and inhibition of the MAPK pathway switching the biological response to FSH from proliferation to differentiation during the maturation process of Sertoli cells 

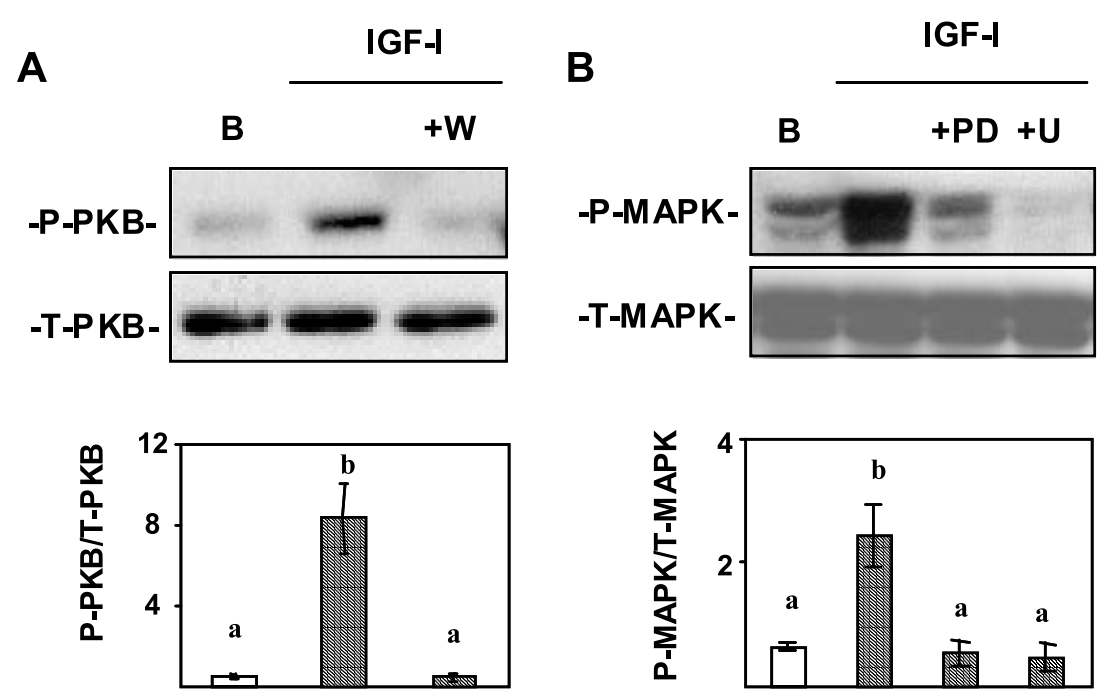

Figure 4 Effect of PI3K and MAPK kinase inhibitors on IGF-l-stimulated P-PKB and P-MAPK levels in 20-day-old rat Sertoli cells. (A) Sertoli cells, either preincubated or not with wortmannin $(\mathrm{W} ; 0 \cdot 1 \mu \mathrm{M})$ for $15 \mathrm{~min}$, were stimulated with $50 \mathrm{ng} / \mathrm{ml} \mathrm{IGF-I} \mathrm{for} 15 \mathrm{~min}$. (B) Sertoli cells, either preincubated or not with PD98059 (PD; $10 \mu \mathrm{M})$ or U0126 (U; $1 \mu \mathrm{M}$ ) for $15 \mathrm{~min}$, were stimulated with $50 \mathrm{ng} / \mathrm{ml}$ IGF-I for 15 min. Cell extracts were prepared and utilized for Western blot analysis using antibodies specific for total PKB (T-PKB) or phosphorylated PKB (P-PKB) and for total MAPK (T-MAPK) or phosphorylated MAPK (P-MAPK). Upper panels show a representative experiment out of three. Lower panels show pooled data of the three independent experiments performed. Results are expressed as the mean \pm S.E. of the ratio between P-PKB and T-PKB or the ratio between P-MAPK and T-MAPK in each sample. Different letters indicate statistically significant differences $(P<0 \cdot 01)$.

(Crepieux et al. 2001). The latter study provides a valuable reference to the demonstration that signal transduction pathways for FSH may vary with the maturation state of Sertoli cells.

As mentioned in the Introduction, the aim of the present study was to analyze the possibility that the observed effects of FSH on P-PKB levels in 20-day-old rats could be explained by an autocrine effect of IGF-I as Khan et al. (2002) proposed for 8-day-old rats. To achieve this goal, it was necessary to analyze possible signal transduction pathways that may be utilized by IGF-I to regulate Sertoli cell function. The present study shows that IGF-I produces higher increments in P-PKB than does FSH. In this way, the possibility that IGF-I secreted by Sertoli cells in response to FSH might be responsible for increasing P-PKB levels in 20-day-old Sertoli cells cannot be ruled out. However, several lines of evidence argue against this conclusion.

First, in 20-day-old Sertoli cells stimulation of P-PKB levels with FSH is seen in 15-min incubations. These observations are different to those presented by Khan et al. (2002) who demonstrated that a 60-min incubation with FSH is necessary to observe an increase in P-PKB levels in 8-day-old Sertoli cells.

Secondly, a marked age-related change in IGF-I-like immunoreactive material has been reported in the rat testis. Up to one week after birth, all cells in the seminiferous tubules show IGF-I-like immunoreactivity. Thereafter, the pattern of IGF-I-like immunoreactivity gradually changes and the Sertoli cells become negative by day 20 of age; in the adult rat it is exclusively localized in the cytoplasm of spermatocytes (Hansson et al. 1989). In addition, Cailleau et al. (1990) showed that FSH does not change the secretion of IGF-I or IGFBPs in 20-day-old Sertoli cells incubated for a short period of time. These observations make it improbable that enough secreted IGF-I in response to FSH may accumulate in the 15-min conditioned medium of 20-day-old Sertoli cells and be responsible for the observed increase in P-PKB levels.

Thirdly, if the actions of FSH were mediated by secreted IGF-I, one would expect to see activation of signal transduction pathways by FSH that are also stimulated by IGF-I. However, the ability of FSH and IGF-I to regulate the MAPK pathway has been shown to be quite different. As expected for a growth factor, IGF-I markedly increased P-MAPK levels while, in agreement with the report by Crepieux et al. (2001), FSH decreased basal steady-state levels of P-MAPK in 20-day-old Sertoli cells. In addition, if the stimulation by FSH of P-PKB levels was mediated by secreted IGF-I, a monoclonal IGF-I antibody would be expected to impair FSH action. Notwithstanding, the IGF-I antibody, while partially blocking the 

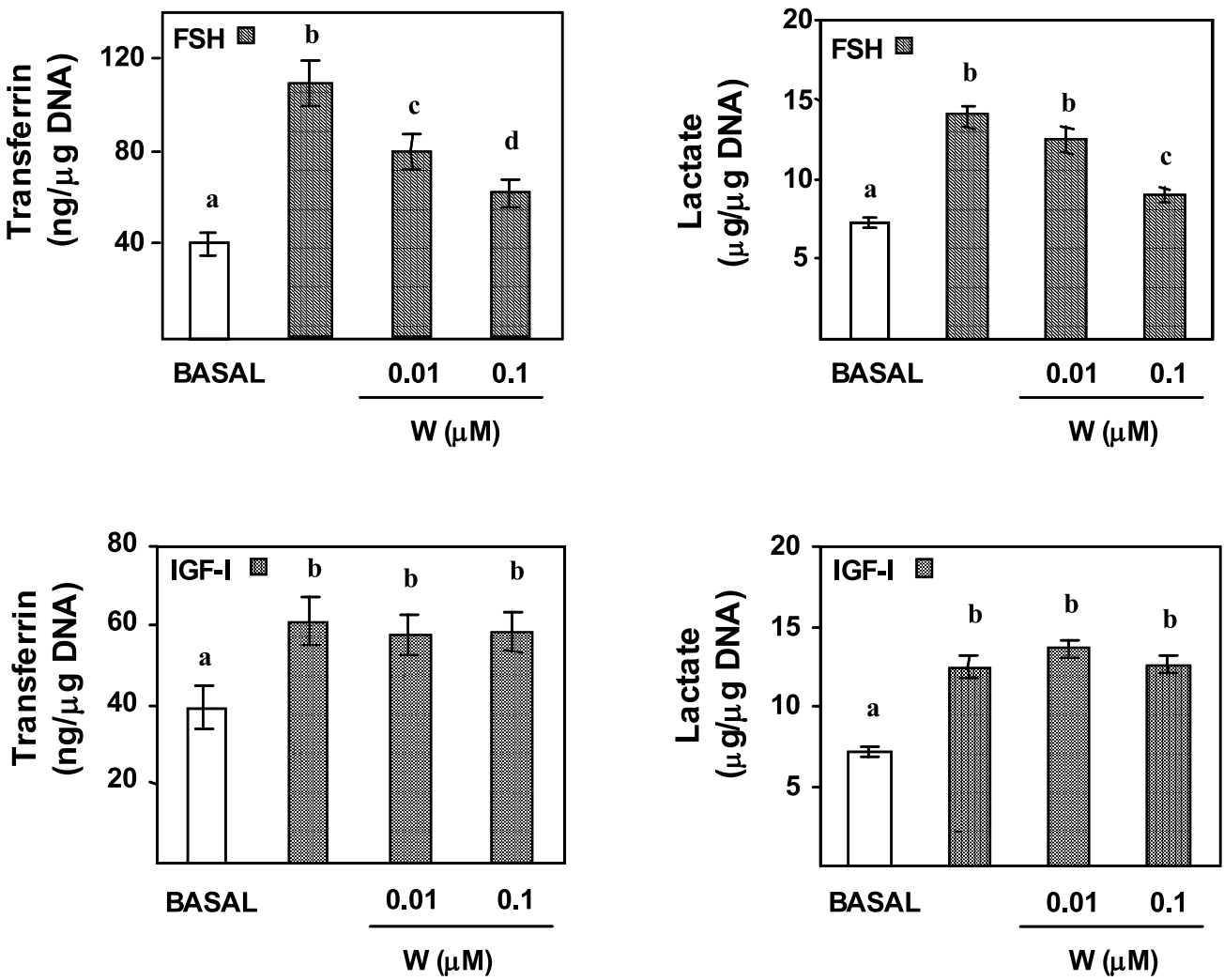

Figure 5 Effect of wortmannin (W) on FSH and IGF-I stimulation of Sertoli cell lactate and transferrin secretion. Sertoli cells were stimulated for $72 \mathrm{~h}$ (day 3 to day 6) with $100 \mathrm{ng} / \mathrm{ml} \mathrm{FSH}$ (upper panels) or $50 \mathrm{ng} / \mathrm{ml}$ IGF-I (lower panels) in the absence or presence of different doses of wortmannin. Transferrin and lactate were determined in the 72-h conditioned media recovered on day 6 . Results represent means \pm S.E. of triplicate incubations in one representative experiment out of three. Different letters indicate statistically significant differences $(P<0 \cdot 01)$.

A

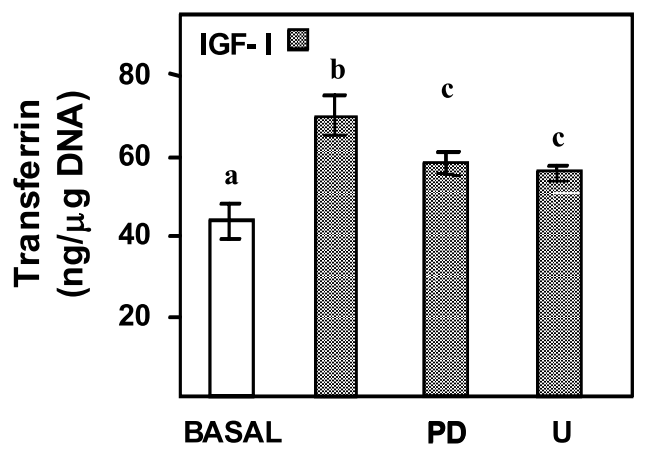

B

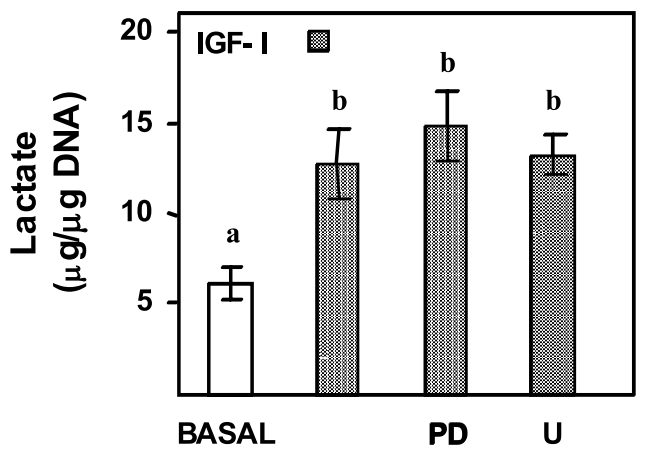

Figure 6 Effect of PD98059 (PD) and U0126 (U) on IGF-I stimulation of Sertoli cell lactate and transferrin secretion. Sertoli cells were stimulated for $72 \mathrm{~h}$ (day 3 to day 6) with $50 \mathrm{ng} / \mathrm{ml}$ IGF-I in the absence or presence of PD98059 $(10 \mu \mathrm{M})$ or U0126 $(1 \mu \mathrm{M})$. Transferrin and lactate were determined in the 72 -h conditioned media recovered on day 6 . Results represent means \pm S.E. of triplicate incubations in one representative experiment out of three. Different letters indicate statistically significant differences $(P<0 \cdot 01)$.

stimulation of exogenously added IGF-I, had no effect on the ability of FSH to stimulate P-PKB levels. This suggests that an IGF-I autocrine effect is not present and it is tempting to speculate that the observed in vitro effects of IGF-I on the function of 20-day-old Sertoli cells constitute the reflection of a paracrine action of IGF-I secreted by 
meiotic spermatocytes. This latter paracrine effect may be contributing to the terminal differentiation of Sertoli cells.

Finally, when the consequences of PI3K and MAPK kinase inhibition on Sertoli cell response to FSH and IGF-I were analyzed, additional evidence to sustain our hypothesis was obtained. As expected, inhibition of PI3K activity with wortmannin decreased P-PKB levels and, conversely, inhibition of MAPK kinase with PD98059 and U0126 decreased P-MAPK levels. Thus, the use of the abovementioned inhibitors in combination with FSH and IGF-I stimulation constituted a useful tool to analyze to what extent the PI3K/PKB and MAPK pathways are involved in FSH and IGF-I regulation of particular Sertoli cell functions.

Two well-known parameters of Sertoli cell function that increase in response to FSH and IGF-I, namely transferrin secretion and lactate production, were evaluated. Previous studies demonstrated that FSH and IGF-I stimulate transferrin secretion (Skinner \& Griswold 1982, Spaliviero \& Handelsman 1991) and lactate production (Mita et al. 1982, Borland et al. 1984). The present study confirms previous observations (Meroni et al. 2002) showing that FSH stimulation of transferrin and lactate production is partially blocked in cells pre-incubated with the PI3K inhibitor, wortmannin. It is noteworthy that no effect of wortmannin was observed in cells stimulated with IGF-I. These results show that even though FSH and IGF-I are able to activate a PI3K/PKB pathway, they do not utilize this signaling pathway in the same way to regulate Sertoli cell function. In addition, albeit indirectly, our results suggest that IGF-I is not responsible for FSH stimulation of transferrin and lactate production.

The above-mentioned results indicated that IGF-I might act through other signaling pathways to regulate transferrin and lactate production. In this context, we observed that the MAPK kinase inhibitors, PD98059 and U0126, partially inhibited the ability of IGF-I to stimulate transferrin secretion suggesting that a MAPK-signaling pathway may be involved. These results are similar to those observed for basic fibroblast growth factor (bFGF) regulation of Sertoli cell transferrin secretion (Riera et al. 2003). In that report it was shown that even when bFGF is able to stimulate MAPK- and PI3K/PKB-dependent pathways in rat Sertoli cells, it only utilizes the MAPKdependent pathway to regulate transferrin secretion.

As for lactate secretion, it was observed that PD98059 and U0126 did not modify the ability of IGF-I to stimulate the production of this energetic metabolite. These results are also similar to those previously observed for bFGF regulation of Sertoli cell lactate secretion (Riera et al. 2003). Altogether, these results seem to point to the fact that growth factors, while being able to regulate a PI3K/ PKB signaling pathway, do not utilize this pathway in the same way as FSH does at this stage of sexual maturation. In this context, a recent report by Zeleznik et al. (2003) indicates that PKB is an obligatory step for FSH-induced granulosa cell differentiation. At the present time, the molecular mechanisms underlying different Sertoli cell behavior when different hormones stimulate the same signal transduction pathway are unknown. However, at least three explanations might be elaborated in an effort to explain the observed phenomena. First, while a PI3K/ PKB signaling pathway may be common to FSH and IGF-I, the cellular context in which this signal develops may be different depending on whether it originates from a $G$ protein-coupled receptor or a growth factor receptor. Secondly, different PKB isoforms, not analyzed so far in rat Sertoli cells, may be differentially regulated by FSH and IGF-I, resulting in a different outcome (Cho et al. 2001). Thirdly, a cellular compartmentalization of the FSH signaling system ultimately directing the correct biological response, as postulated for granulosa cells (Conti 2002), may exist.

In summary, the present investigation shows that: (a) IGF-I stimulates MAPK- and PI3K/PKB-dependent pathways in 20-day-old Sertoli cells, (b) a specific IGF-I antibody does not impair the ability of FSH to stimulate P-PKB levels and (c) FSH and IGF-I utilize differently the $\mathrm{PI} 3 \mathrm{~K} / \mathrm{PKB}$ signal transduction pathway to regulate Sertoli cell function. These results suggest that the action of FSH on P-PKB levels and Sertoli cell metabolism in 20-day-old animals is not mediated by an autocrine effect of IGF-I. In addition, and from a broader perspective, these results add support to the hypothesis that within the same cell type several hormones sharing a particular signal transduction pathway may utilize it differently to regulate cell function.

\section{Acknowledgements}

We thank Dr A Parlow from NIDDK for the gift of oFSH and monoclonal IGF-I antibody. The technical help of Mercedes Astarloa is gratefully acknowledged. We also thank Celia Nieto for revising our English usage.

\section{Funding}

This work was supported by grants from CONICET and the Agencia Nacional de Promoción Científica y Tecnológica, Argentina. M S B and C S B are established investigators of CONICET.

\section{References}

Borland K, Mita M, Oppenheimer CL, Blinderman LA, Massague J, Hall PF \& Czech MP 1984 The actions of insulin-like growth factors I and II on cultured Sertoli cells. Endocrinology 114 240-246. Cailleau J, Vermeire S \& Verhoeven G 1990 Independent control of the production of insulin-like growth factor I and its binding protein by cultured testicular cells. Molecular and Cellular Endocrinology 69 79-89. 
Cass LA, Summers SA, Prendergast GV, Backer JM, Birbaum MJ \& Meinkoth JL 1999 Protein kinase A-dependent and -independent signaling pathways contribute to cyclic AMP-stimulated proliferation. Molecular and Cellular Biology 19 5882-5891.

Cho H, Thorvaldsen JL, Chu Q, Feng F \& Birbaum MJ 2001 $\mathrm{Akt} / \mathrm{PKBa}$ is required for normal growth but dispensable for maintenance of glucose homeostasis in mice. Journal of Biological Chemistry 276 38349-38352.

Conti M 2002 Specificity of the cyclic adenosine 3',5'-monophosphate signal in granulosa cell function. Biology of Reproduction $\mathbf{6 7}$ 1653-1661.

Crepieux P, Marion S, Martinat N, Fafeur V, Vern YL, Kerboeuf DF \& Reiter E 2001 The ERK-dependent signaling is stage-specifically modulated by FSH during primary Sertoli cell maturation. Oncogene 20 4696-4709.

Delfino F \& Walker WH 1998 Stage-specific nuclear expression of NF- $\mathrm{KB}$ in mammalian testis. Molecular Endocrinology 12 1696-1707.

Gonzalez-Robayna I, Falender A, Ochsner S, Firestone G \& Richards J 2000 FSH stimulates phosphorylation and activation of protein kinase $\mathrm{B}(\mathrm{PKB} / \mathrm{Akt})$ and serum and glucocorticoid-induced kinase (Sgk): evidence for A kinase-independent signaling by FSH in granulosa cells. Molecular Endocrinology 14 1283-1300.

Gorczynska E \& Handelsman D 1991 The role of calcium in FSH signal transduction in Sertoli cells. Journal of Biological Chemistry 266 23739-23744.

Grasso P \& Reichert L 1989 FSH receptor-mediated uptake of ${ }^{45} \mathrm{Ca}^{2+}$ by proteoliposomes and cultured rat Sertoli cells: evidence for involvement of voltage-activated and voltage-independent calcium channels. Endocrinology 125 3029-3036.

Griswold MD 1993 Actions of FSH on mammalian Sertoli cells. In The Sertoli Cell, pp 493-508. Eds LD Russell \& MD Griswold. Clearwater: Cache River Press.

Handelsman DJ, Spaliviero JA, Kidston E \& Robertson DM 1989 Highly polarized secretion of inhibin by Sertoli cells in vitro. Endocrinology 125 721-729.

Hansson HA, Billig H \& Isgaard J 1989 Insulin-like growth factor-I in the developing and mature rat testis: immunohistochemical aspects. Biology of Reproduction 40 1321-1328.

Jannini E, Ulisse S \& Cecconi S 1994 Follicle-stimulating hormone-induced phospholipase A2 activity and eicosanoid generation in rat Sertoli cells. Biology of Reproduction 51 140-145.

Khan SA, Ndjountche L, Pratchard L, Spicer LJ \& Davis JS 2002 Follicle-stimulating hormone amplifies insulin-like growth factor-I-mediated activation of AKT/protein kinase B signaling in immature rat Sertoli cells. Endocrinology 143 2259-2267.

Labarca C \& Paigen K 1980 A simple, rapid and sensitive DNA assay procedure. Analytical Biochemistry 102 344-352.

Laemmli UK 1970 Cleavage of structural proteins during the assembly of the head of bacteriophage $T_{4}$. Nature 277 680-685.

Lambert A, Talbot JA, Mitchell R \& Robertson WR 1991 Inhibition of protein kinase $\mathrm{C}$ by staurosporine increases estrogen secretion by rat Sertoli cells. Acta Endocrinologica 125 286-290.
Meroni SB, Canepa DF, Pellizzari EH, Schteingart HF \& Cigorraga SB 1997 Regulation of $\gamma$-glutamyl transpeptidase activity by $\mathrm{Ca}^{2+}$ and protein kinase C-dependent pathways in Sertoli cells. International Journal of Andrology 20 189-194.

Meroni SB, Canepa DF, Pellizzari EH, Schteingart HF \& Cigorraga SB 1999 Effect of $\mathrm{N}$-acetylsphingosine (c2) and ceramidase inhibitor (1S,2R)-D-erythro-2-(N-myristoylamino)-1-phenyl-1propanol on the regulation of Sertoli cell function. Journal of Andrology 20 619-625.

Meroni SB, Riera MF, Pellizzari EH \& Cigorraga SB 2002 Regulation of rat Sertoli cell function by FSH: possible role of phosphatidylinositol 3-kinase/protein kinase B pathway. Journal of Endocrinology 174 195-204.

Mita M, Price JM \& Hall PF 1982 Stimulation by follicle-stimulating hormone of synthesis of lactate by Sertoli cells from rat testis. Endocrinology 110 1535-1541.

Monaco L, Adamo S \& Conti M 1988 FSH modulation of phosphoinositide turnover in the immature rat Sertoli cell in culture. Endocrinology 123 2032-2039.

Orth JM 1982 Proliferation of Sertoli cells in fetal and postnatal rats: a quantitative autoradiographic study. Anatomical Record 203 485-492.

Orth JM 1984 The role of follicle-stimulating hormone in controlling Sertoli cell proliferation in testes of fetal rats. Endocrinology 125 $1248-1255$

Richards JS 2001 New signaling pathways for hormones and cyclic adenosine 3',5'-monophosphate action in endocrine cells. Molecular Endocrinology 15 209-218.

Riera MF, Meroni SB, Pellizzari EH \& Cigorraga SB 2003 Assessment of the roles of mitogen-activated protein kinase and phosphatidyl inositol 3-kinase/protein kinase B pathways in the basic fibroblast growth factor regulation of Sertoli cell function. Journal of Molecular Endocrinology 31 279-289.

Skinner MK \& Griswold MD 1982 Secretion of testicular transferrin by cultured Sertoli cells is regulated by hormones and retinoids. Biology of Reproduction 27 211-221.

Spaliviero JA \& Handelsman DJ 1991 Effect of epidermal and insulin-like growth factors on vectorial secretion of transferrin by rat Sertoli cells in vitro. Molecular and Cellular Endocrinology 81 95-104.

Steinberger A, Hintz M \& Heindel JJ 1978 Changes in cyclic AMP responses to FSH in isolated rat Sertoli cells during sexual maturation. Biology of Reproduction 19 566-572.

Zeleznik AJ, Saxena D \& Little-Ihrig L 2003 Protein kinase B is obligatory for follicle-stimulating hormone-induced granulosa cell differentiation. Endocrinology 144 3985-3994.

Received in final form 23 October 2003

Accepted 14 November 2003

Made available online as an Accepted Preprint 25 November 2003 